\title{
高マグネシア酸化ニッケル鉱の還元アンモニア 浸出に及ぼすジャロサイト添加の影響*
}

\author{
姚 良 均 ${ }^{1}$ 河 原 正 泰 $^{2}$ \\ 白 根 義 則 ${ }^{3}$
}

1. 緒言

ガーニエライトの還元反応の $\mathrm{MgO}$ の依存性 ${ }^{1) \sim 5)}$ から, 高 マグネシア酸化ニッケル鉱は難還元性鉱として知られてい る。本研究では, $\mathrm{MgO}$ 含量 $30 \%$ 以上の高マグネシア酸化 ニッケル鉱であるウィネ鉱の還元アンモニア浸出を行ない, $\mathrm{Ni}$, Co および $\mathrm{Mg}$ の浸出率に及ぼす還元焙焼条件の影響を 検討した。

一方，湿式車鉛製鍊においてジャロサイト法は非常に有 効な浄液手段であるが，生成するジャロサイトの処理法が 確立していないため, その蓄積が問題となつている。年7) 前

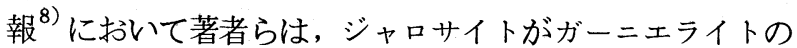
良好な硫酸化剂として作用することを見出した。そこで本 研究では, ジャロサイトの有効利用の一環として, ウィネ 鉱にジャロサイトを添加することにより，被還元性を向上 させることを試みた。

2. 試料

高マグネシア酸化ニッケル鉱は日本鉱業（株）佐賀関製 鍊所より提供していただたニューカレドニア産のウィネ 鉱で,ボールミルでー 200 mesh に整粒したものを用いた。

第 1 表 ウィネ鉱の化学分析組成

(wt \%)

\begin{tabular}{|c|c|c|c|}
\hline $\mathrm{Ni}$ & $\mathrm{Co}$ & $\mathrm{Fe}$ & $\mathrm{MgO}$ \\
\hline 2.48 & 0.083 & 10.06 & 30.33 \\
\hline \hline $\mathrm{SiO}_{2}$ & $\mathrm{Al}_{2} \mathrm{O}_{3}$ & $\mathrm{CaO}$ & Ig. loss \\
\hline 38.10 & 1.16 & 0.08 & 11.18 \\
\hline
\end{tabular}

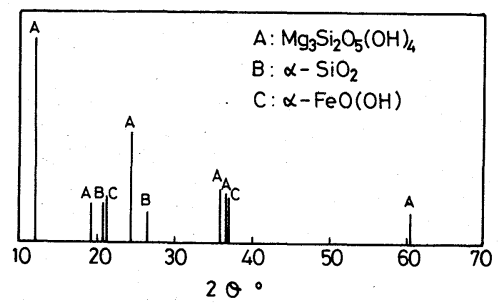

第 1 図 ウィネ鉱のX線回折パターン

* 1981 年 12 月 25 日受理

1. 熊本大学工学部研究生 (現 中華人民共和国 - 北京鉱治研究総院 )

2. 正会員 工博 熊本大学助手 工学部金属工学科

3. 正会員 工博 熊本大学教授 工学部金属工学科
この化学分析組成を第 1 表に示す。 $\mathrm{Ni}$ 品位は約 $2.5 \%$ で あるが， $\mathrm{MgO}$ を 30 \%以上も含有している。一般のガーニ エライトの $\mathrm{MgO} / \mathrm{Ni}$ 比は約 1.2 (緑色鉱) ～7 (褐色鉱) で, $\mathrm{MgO} / \mathrm{Ni}$ 比が大きいほど難還元性となる。 験に用いたウィネ鉱は $\mathrm{MgO} / \mathrm{Ni}$ 比が 10 以上もあり,ガー ニェライトの中でも非常な難還元性鉱として知られている。 第1 図には本鉱のX線回折パターンを示した。ガーニェラ イト特有のサーペンチン $\left(\mathrm{Mg}_{3} \mathrm{Si}_{2} \mathrm{O}_{5}(\mathrm{OH})_{4}\right)$ のピーク， $\alpha$ コルッ $\left(\alpha-\mathrm{SiO}_{2}\right)$ およびゲーサイト $(\alpha-\mathrm{FeO}(\mathrm{OH})) の$ ピークが確認された。

一方, 添加剤の $\mathrm{Fe}_{2}\left(\mathrm{SO}_{4}\right)_{3}$ ならびにカリジャロサイトは 研究室で合成し，X線回折により確認したものを用いた。 これらの化学分析組成は，いずれも化学量論組成とほぼ一 致した。

\section{3. 実験装置および実験方法}

本実験で用いた還元焙焼装置の略図を第 2 図に示した。 炉はニクロム線電気抵抗炉を用い, 自動温度調整ができる ようにした。水素ガスを所定温度に加熱した水にくぐらせ， 所定の水素濃度の水素 - 水蒸気混合ガスを得た。また, 還 元ガス導入管にニクロム線を巻き加熱し, 水蒸気の凝縮を 防止した。還元焙焼温度は $673 \sim 1173 \mathrm{~K}$ 水素一水蒸気

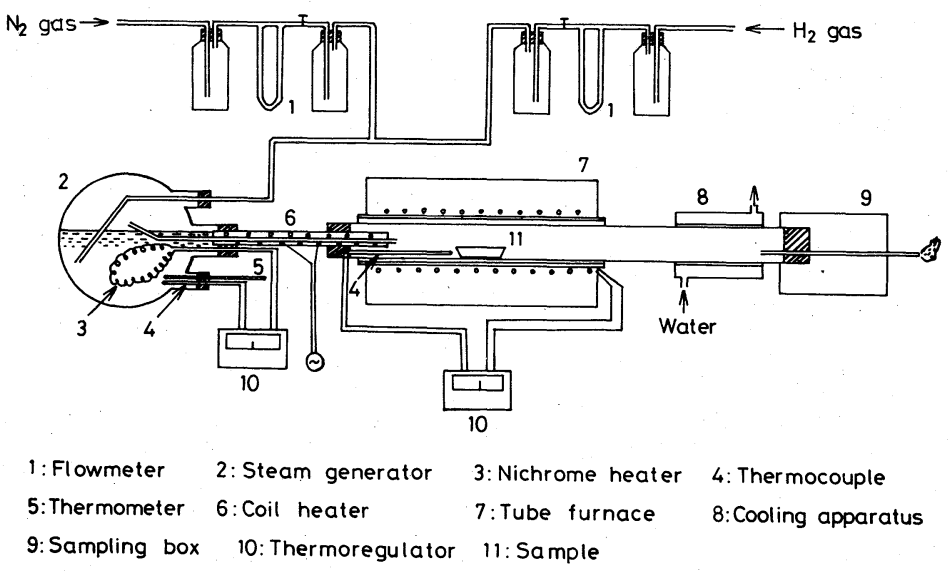

第 2 図還元焙焼実験装置

混合ガス中の水素濃度 ( 体積百分率 ) は $10 \sim 99.9 \%$ と変 化させ，焙焼を行なつた。還元は窒素ガス気流中で所定温 度に加熱後，水素一水蒸気混合ガスに切りかえる予熱還元 
と, 常温から水素一水蒸気混合ガスで還元しながら所定温 度まで昇温する昇温同時還元を行なつた。このときの昇温 速度は $15 \mathrm{~K} / \mathrm{min}$ で, 所定温度に到達後, 30 分間定温還元 を行なつた。また，焙焼に供した試料は一回につき $0.5 \mathrm{~g}$ ， 水素ガス流量は $200 \mathrm{ml} / \mathrm{min}$ 一定とした。

還元焙焼後の試料は炉の出口に相当距離引出して急冷し, $\mathrm{CO}_{2}$ を満たしたSampling boxに取り出し，酸化を防止し た。この焼鉱は值ちに $6.5 \% \mathrm{NH}_{3}, 3.75 \% \mathrm{SO}_{3}$ のアンモニ ア一硫酸アンモン溶液 $200 \mathrm{ml}$ で, 湯浴 $\left(45^{\circ} \mathrm{C}\right)$ 中, 2 時 間, 浸出を行なつた。浸出液中および残渣中の $\mathrm{Ni}, \mathrm{Co}, \mathrm{Mg}$ は原子吸光分析法により定量し, それぞれの元素の浸出率 を求めた。なお，用いた原子吸光分析装置は Japan Jarrel Ash 製A A - 80 型である。

\section{4. 実験結果および考察}

\section{$4 \cdot 1$ ウィネ鉱の還元アンモニア浸出}

ガーニェライトはラテライトより難還元性であり，また， $\mathrm{MgO}$ 含量の増加により $\mathrm{Ni}$ の被還元性は低下することが知

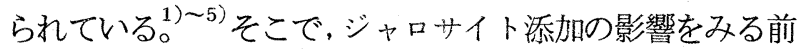
に, ウィネ鉱単味の還元アンモニア浸出を行ない，本鉱の 被還元性を検討した。

第3 図は, 予熱還元と昇温同時睘元について, $\mathrm{Ni}, \mathrm{Co}$, $\mathrm{Mg}$ の浸出率に及代す還元焙焼温度の影響をみたものであ る。いずれも水素一水蒸気混合ガス中の水素濃度は 50 \% , 焙焼時間は 30 分である。予熱還元と昇温同時還元では, $\mathrm{Mg}$ の浸出率にはほとんど差はないが，Ni，Coの浸出率は

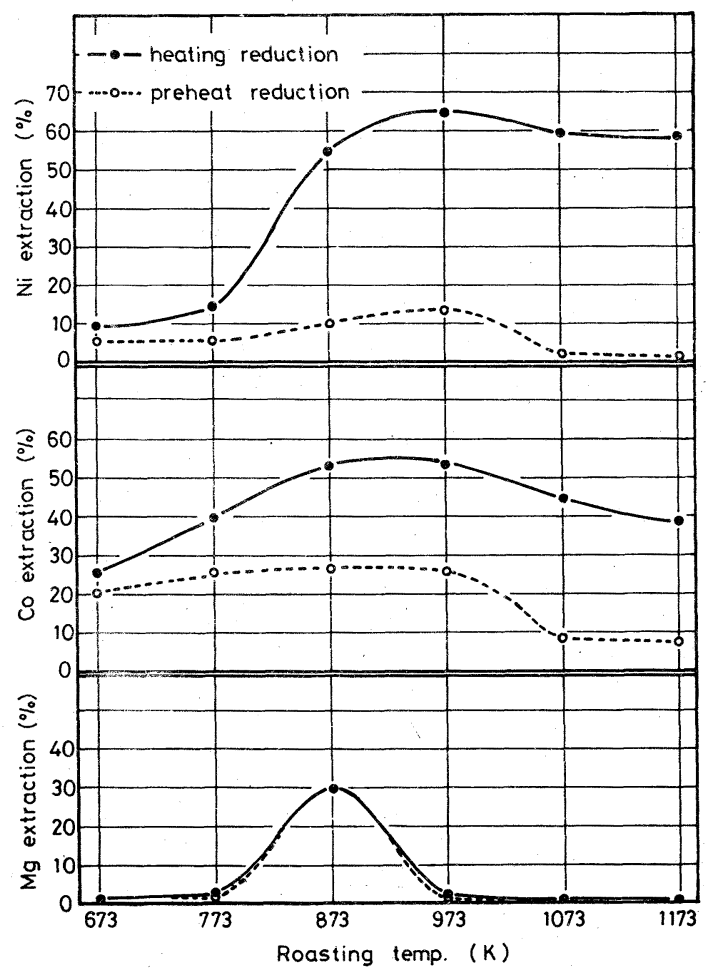

第 3 図 $\mathrm{Ni}, \mathrm{Co}_{0}, \mathrm{Mg}$ の浸出率と還元哣焼温度の関俰 （ウィネ鈗単味， $\mathrm{H}_{2}$ 濃度 $50 \%$, 焙焼時間 30 分)
常温から還元を開始した昇温同時還元のほうが高くなつた。 。また，その効果はNi の浸出率に著しく大きく現われた。

$\mathrm{Ni}$, Co の浸出率は還元温度 $973 \mathrm{~K}$ で極大値を示し, 昇温 同時還元では, Ni は約 $65 \%$, Co は約 $55 \%$ 浸出された。 またこれより高温になると， $\mathrm{Ni} ， \mathrm{Co}$ の浸出率はともに 低下する傾向を示した。

$\mathrm{Ni}$ の浸出率変化に現われたこれらの現象は, Caron, Bold $\mathrm{t}^{10)}$ ならびに著者ら ${ }^{1) \sim 4)}$ の過去の研究にもみられ， 次のように考察される。

ガーニエライトの加熱に際して起こる反応は次の(1) (3) 式で表わされる。

$\left(\mathrm{Mg}_{1-x} \mathrm{Ni}_{x}\right)_{3} \mathrm{Si}_{2} \mathrm{O}_{5}(\mathrm{OH})_{4}$

$=2\left(\mathrm{Mg}_{1-x} \mathrm{Ni} x\right) \mathrm{O}+\left(\mathrm{Mg}_{1-x} \mathrm{Ni}_{x}\right) \mathrm{Si}_{2} \mathrm{O}_{5}+2 \mathrm{H}_{2} \mathrm{O}$

$4\left(\mathrm{Mg}_{1-x} \mathrm{Ni} x\right) \mathrm{O}+2\left(\mathrm{Mg}_{1-x} \mathrm{Ni}_{x}\right) \mathrm{Si}_{2} \mathrm{O}_{5}$

$=3\left(\mathrm{Mg}_{1-x} \mathrm{Ni}_{x}\right)_{2} \mathrm{SiO}_{4}+\mathrm{SiO}_{2}$

$3\left(\mathrm{Mg}_{1-x} \mathrm{Ni}_{x}\right)_{2} \mathrm{SiO}_{4}+\mathrm{SiO}_{2}$

$=2\left(\mathrm{Mg}_{1-x} \mathrm{Ni}_{x}\right)_{2} \mathrm{SiO}_{4}+2\left(\mathrm{Mg}_{1-x} \mathrm{Ni} x\right) \mathrm{SiO}_{3}$

ここで，(1)式の脱水反応は約 $873 \mathrm{~K} て ゙ ，(2) ，(3)$ 式の再結

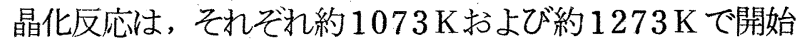
する。 ${ }^{4) 8)}$ (2)式の再結晶化が進行すると, Niはシリケート (フォルステライト) 中に固溶されるため, $\mathrm{Ni}$ の被還元性 は低下する。そこで, ガーニェライトの還元には，(2)式の 反応が起こる手前の温度である $973 \mathrm{~K}$ 付近での焙焼が有利 であり 立本実験結果にも,この影響が現われたものと推察

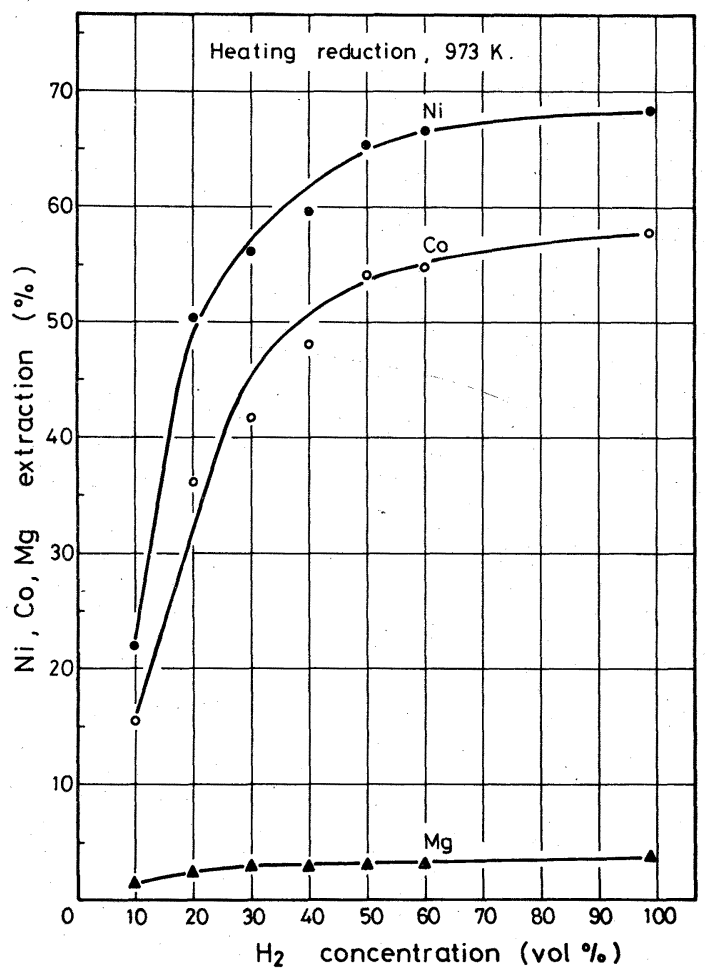

第 4 図 混合ガス中の水素濃度と $\mathrm{Ni}, \mathrm{Co}, \mathrm{Mg}$ の浸出率の 関係 $(973 \mathrm{~K}$, 昇温同時還元) 


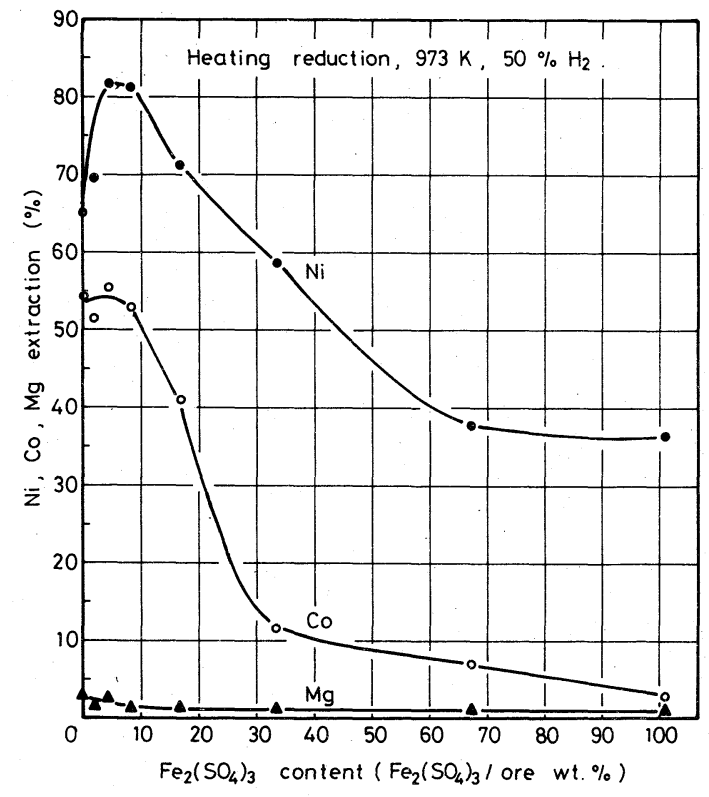

第 5 図 $\mathrm{Ni}, \mathrm{Co}_{0}, \mathrm{Mg}$ の浸出率に及ぼす硫酸第 2 鉄添加量の 影響 $\left(973 \mathrm{~K}\right.$, 昇温同時還元, $\mathrm{H}_{2}$ 濃度 $\left.50 \%\right)$

される。また，常温からの昇温同時還元では，(1)式の反応 で生成する $\left(\mathrm{Mg}_{1-x} \mathrm{Ni}_{x}\right) \mathrm{O}$ (以下これを無定形酸化物 ${ }^{8)}$ と 呼ぶ ) がフォルステライトに再結晶することなく還元され やすいので, 予熱還元と比較して, Ni 浸出率が高くなつ たものと思われる。以後の結果は, 特にことわらない限り, 常温からの昇温同時還元による結果である。

第 4 図には, $973 \mathrm{~K}$ での昇温同時還元における, 水素一 水蒸気混合ガス中の水素濃度と $\mathrm{Ni}, \mathrm{Co}, \mathrm{Mg}$ の浸出率の関 係を示した。水素濃度が高いほど， $\mathrm{Ni} ， \mathrm{Co}$ の浸出率は向 上するが, 水素濃度が 50 \%以上になると, 浸出率の増加 割合は鈍化する傾向にある。一般のラテライトでは, 強還 元性雲囲気で焙焼すると, $\mathrm{Ni}$ の浸出率はむしろ低下し, これは共存する鉄の影響と推察されている。 ウィネ鉱は鉄量が約 $10 \%$ で, ラテライトに比べて鉄量が少 ないため, 強還元性焙焼による Ni 浸出率の低下現象が現 われなかつたものと思われる。

\section{$4 \cdot 2$ 硫酸第 2 鉄添加の影響}

前報 $^{8)}$ において著者らは, ジャロサイトならびに硫酸第 2 鉄がガーニエライトの有効な硫酸化剂になることを見出 した。これは $\mathrm{Fe}_{2}\left(\mathrm{SO}_{4}\right)_{3}$ の熱分解によつて生じる $\mathrm{SO}_{3}$ ガス が，先の(1)式で生成するメタガーニエライト相中の無定形 酸化物ならびに無定形珪酸塩に固定するためと推定した。 今回のような還元焙焼では, 発生する $\mathrm{SO}_{3}$ ガスは水素と反 応して, 次式のように硫化水素と水になる。

$$
\mathrm{SO}_{3}+4 \mathrm{H}_{2}=\mathrm{H}_{2} \mathrm{~S}+3 \mathrm{H}_{2} \mathrm{O}
$$

この $\mathrm{H}_{2} \mathrm{~S}$ は(1)式で生じる無定形酸化物を一時的に硫化し， (2)式の再結晶化反応を防止し, 被還元性を向上させると思 われるため,まず，硫酸第 2 鉄添加の影響を検討した。

第 5 図には, 硫酸第 2 鉄添加量と $\mathrm{Ni}, \mathrm{Co}, \mathrm{Mg}$ の浸出率 の関係を示した。焙焼条件は水素濃度 $50 \%, 973 \mathrm{~K}$ にお

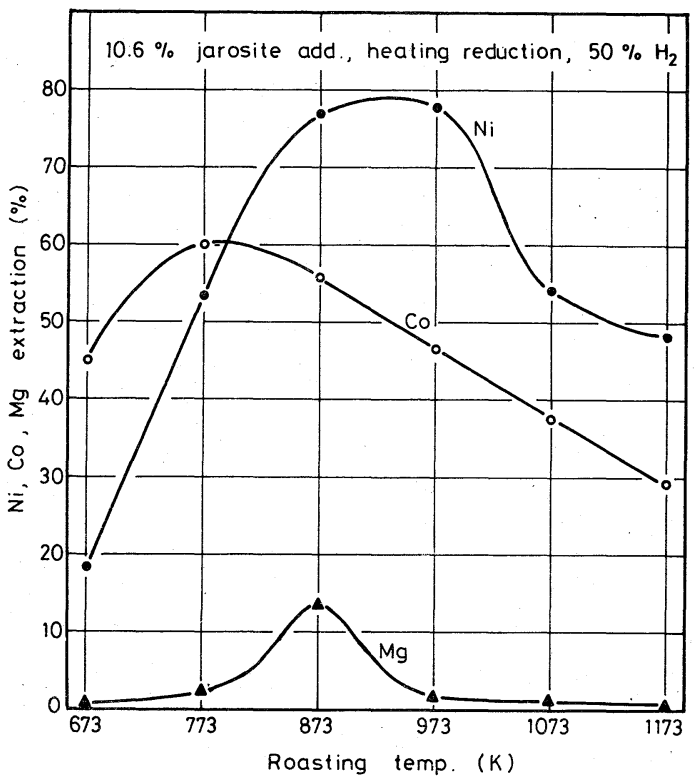

第 6 図 $\mathrm{Ni}, \mathrm{Co}, \mathrm{Mg}$ の浸出率と還元焙焼温度の関係( ジャロ サイト $10.6 \%$ 添加, 昇温同時還元, $\mathrm{H}_{2}$ 濃度 $50 \%$ )

ける昇温同時還元で, 30 分間の定温還元を行なつた。 $\mathrm{Mg}$ の浸出率は, いずれの場合も $2 \%$ 以下で, 硫酸第 2 鉄添加 の影響はみられない。 $\mathrm{Ni}$ 浸出率は，硫酸第 2 鉄を $5 \sim 10$ \%添加すると， $65 \%$ (硫酸第 2 鉄無添加のとき) から約 $81 \%$ 向上する。Co浸出率は硫酸第 2 鉄添加量約 $10 \%$ ま で, ほとんど変化しないが, 添加量がこれより多くなると, $\mathrm{Ni}$ とCoの浸出率は, ともに低下する傾向を示した。この 浸出率の低下は硫化物として残存する $\mathrm{Ni}, \mathrm{Co}$ の量が増す ためと思われる。また, ウィネ鉱単味の場合の $\mathrm{Ni}$ 浸出率 がたかだか $68 \%$ 程度 (第 4 図) であるのに対し，硫酸第 2 鉄を比較的少量添加すると, $\mathrm{Ni}$ 浸出率が 80 \%以上になる のは非常に興味深い。

\section{$4 \cdot 3$ ジャロサイト添加の影響}

カリジャロサイトの加熱に際して起こる反応は, 次の(5), (6)式で示される。112)

$$
\begin{aligned}
& 2 \mathrm{KFe}_{3}\left(\mathrm{SO}_{4}\right)_{2}(\mathrm{OH})_{6} \\
& \quad=\mathrm{K}_{2} \mathrm{SO}_{4} \cdot \mathrm{Fe}_{2}\left(\mathrm{SO}_{4}\right)_{3}+2 \mathrm{Fe}_{2} \mathrm{O}_{3}+6 \mathrm{H}_{2} \mathrm{O}
\end{aligned}
$$

$\mathrm{K}_{2} \mathrm{SO}_{4} \cdot \mathrm{Fe}_{2}\left(\mathrm{SO}_{4}\right)_{3}=\mathrm{K}_{2} \mathrm{SO}_{4}+\mathrm{Fe}_{2} \mathrm{O}_{3}+3 \mathrm{SO}_{3} \cdots \cdots$ (6)

ここで, (5)式の脱水反応は約 $573 \mathrm{~K} て ゙,(6)$ 式の脱硫反応 は約 $873 \mathrm{~K}$ で開始する。112) ${ }^{1 \text { 前報 }}{ }^{8)}$ においては, (6)式の反 応温度と前述の(1)式の反応温度がほぼ等しいため, ジャロ サイトはガーニエライトの有効な硫酸化剂になると報告し た。そこで, ジャロサイトを混合して還元焙焼すると, 硫 酸第 2 鉄を添加した場合と同様, $\mathrm{Ni}$ 浸出率の向上が期待 される。

第 6 図には,ジャロサイトを約 $10 \%$ 添加し, 水素濃度 50 $\%$ 水素一水蒸気混合ガスで昇温同時還元したときの, 焙 焼温度と $\mathrm{Ni}, \mathrm{Co}, \mathrm{Mg}$ の浸出率の関係を示した。 Niの浸出 率は,やはり $973 \mathrm{~K}$ で焙焼したとき極大值を示し, Ni の $80 \%$ 近くが浸出された。Coの浸出率は $773 \mathrm{~K}$ での焙焼 


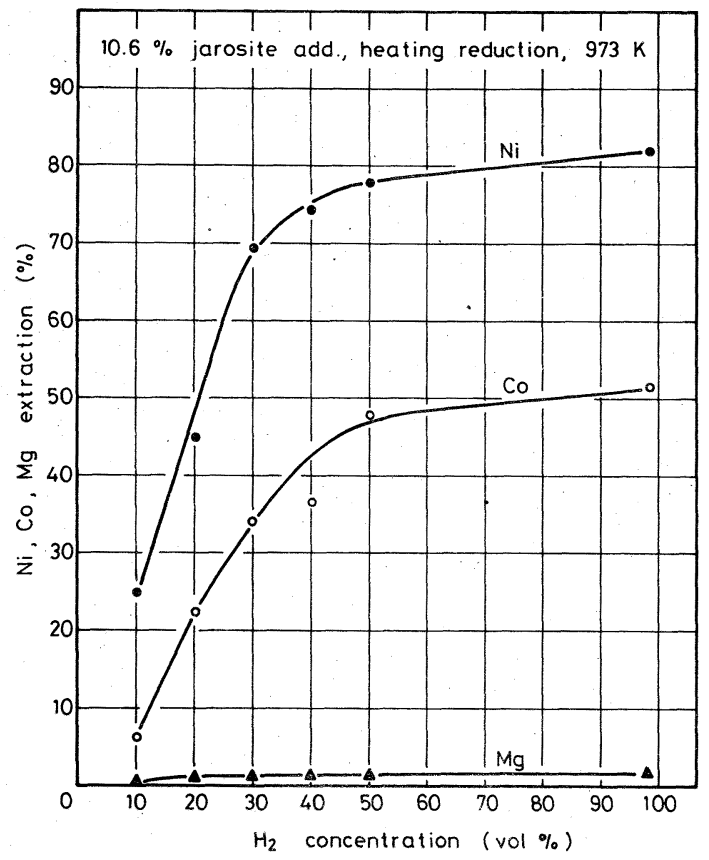

第 7 図、混合ガス中の水素濃度と $\mathrm{Ni}, \mathrm{Co}, \mathrm{Mg}$ の浸出率の関係 (ジャロサイト $10.6 \%$ 添加, 973K, 昇温同時還元)

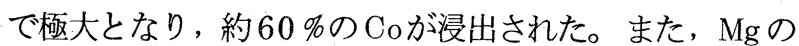
浸出率は用いたウィネ鉱単味の $\mathrm{Mg}$ の浸出率の変化(第3図) とほぼ同じ傾向を示した。

第 7 戝は，同じくジャロサイトを約 $10 \%$ 添加し, $973 \mathrm{~K}$ で昇温同時還元したときの, 混合ガス中の水素濃度と $\mathrm{Ni}$, $\mathrm{Co}, \mathrm{Mg}$ の浸出率の関係をみたものである。ウィ不鉱単味 の場合 (第 4 図) と同様, $\mathrm{H}_{2}$ 濃度が高いほど $\mathrm{Ni}, \mathrm{Co}$ の浸 出率は向上するが, $\mathrm{H}_{2}$ 濃度 $50 \%$ 以上では, 浸出率の増加 割合はにぶる傾向を示した。

第 8 図には, ジャロサイト添加量と $\mathrm{Ni}, \mathrm{Co}, \mathrm{Mg}$ の浸出 率の関係を示した。焙焼条件は水素濃度 $50 \%, 973 \mathrm{~K}$ に おける昇温同時還元である。 $\mathrm{Mg}$ の浸出率にはジャロサイト 添加の影響は現われない。 $\mathrm{Ni}$ 浸出率はジャロサイト添加量 約 $10 \%$ まで急激に増加し, その後, 添加量の増加とともに 浸出率は低下寸る傾向を示した。Coの浸出率は, ジャロサ イト添加量の増加とともに，次第に低下した。これらの結 果は，硫酸第 2 鉄を添加した場合 ( 第 5 図 ) とほぼ同じ傾 向を示している。

今回の実験から, ウィネ鉱に硫酸第 2 鉄もしくはジャ口 サイトを比較的少量添加し，還元焙焼を行なうと，アンモ ニア浸出におるける $\mathrm{Ni}$ 浸出率が著しく向上することが判明し た。そこで，硫黄一酸素ポテンシャル状態図を用い，以上 の結果を考察する。

第 9 図に, 関係元素の $973 \mathrm{~K}$ に抢ける硫黄一酸素ポテン シャル状態図を示した。状態困決定には, 最新の熱力学デ 一タ ${ }^{13)}$ を用いた。図中，太い実線が $\mathrm{Ni}$ の状態変化,二点鎖 線が $\mathrm{Co}$ の状態変化，破線が $\mathrm{Fe}$, 一点鎖線が $\mathrm{Mg}$ の状態変 化を示したものである。なお，今回の実験雾囲気は図中斜

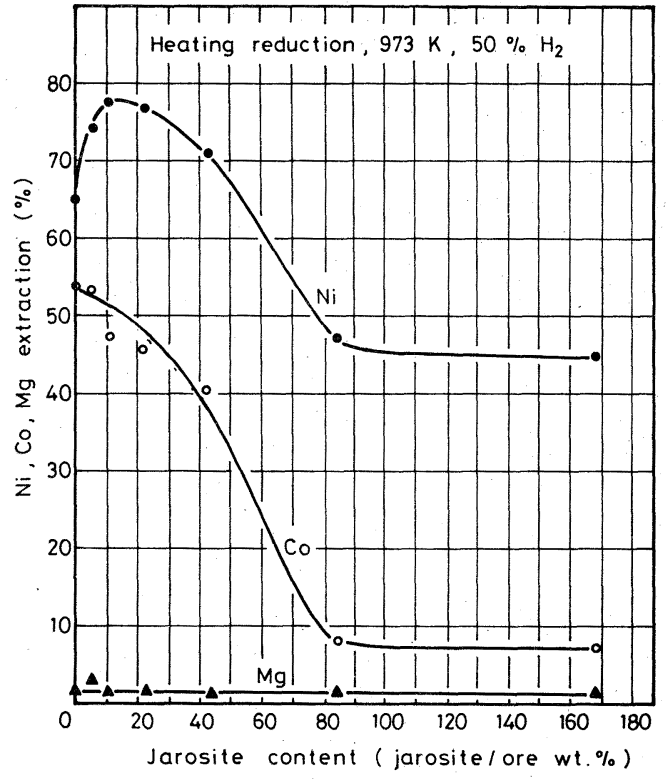

第 8 図 $\mathrm{Ni}, \mathrm{Co}, \mathrm{Mg}$ の浸出率に及ぼすジャロサイト添加量 の影響 $\left(973 \mathrm{~K}\right.$, 昇温同時還元, $\mathrm{H}_{2}$ 濃度 $\left.50 \%\right)$

線で示した範囲であるので, $\mathrm{Ni}, \mathrm{Co}, \mathrm{Fe}$ の硫酸塩が生成 する境界線は省略した。ここで, ジャロサイト添加量が比 較的少ないとき, ジャロサイトの熱分解 ((6) 式)によつて 発生する $\mathrm{SO}_{3}$ が水素之反応 ( (4) 式) し $\mathrm{H}_{2} \mathrm{~S}$ となり,ガーニエ ライトの脱水反応 ( (1) 式) で生成する無定形酸化物を硫化 し，一時的にNi は硫化物になると思われる。 Ni が硫化物 になると，被還元性低下の原因であるフォルステライトー の再結晶化 ( (2) 式) が抑えられ, この状態で $\mathrm{H}_{2} \mathrm{~S}$ 分圧の低 下により, Ni は金属状態まで還元されると思われ,これら の経過はNi 浸出率の向上につながる。一方, ジャロサイト 添加量が多くなると, $\mathrm{H}_{2} \mathrm{~S}$ 分圧が比較的高いまま焙焼を終 えることになり，硫化物として残存する量が増加し，浸出 率も低下するものと思われる。

以上の考察を検討するため, アンモニア浸出残渣中の硫 化物としての $\mathrm{Ni}$, Co 量を臭素メタノール法 ${ }^{14) 15)}$ により定量 した。実験結果を第 2 表に示す。ここで, ジャロサイト添 加量および還元焙焼条件は第 8 図に示したものと同一であ

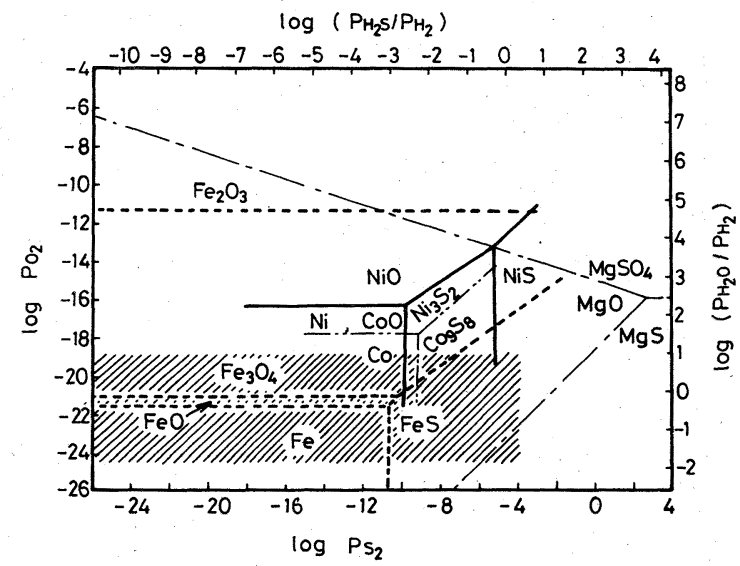

第9図 関係元素の硫黄一酸素ポテンシャル状態図 $(973 \mathrm{~K})$ 
第 2 表 アンモニア浸出およびその残渣の臭素メタノール浸出 における Ni, Coの唚出率とジャロサイト添加量の関係 ( $973 \mathrm{~K}$, 昇温同時還元, $\mathrm{H}_{2}$ 濃度 $50 \%$ )

\begin{tabular}{|c|c|c|c|c|}
\hline \multirow{2}{*}{$\begin{array}{c}\text { Jarosite content } \\
\text { (jarosite/ore, wt.\%) }\end{array}$} & \multicolumn{2}{|c|}{$\begin{array}{l}\text { Ammonia leaching } \\
\text { (Extraction \%) }\end{array}$} & \multicolumn{2}{|c|}{$\begin{array}{l}\text { lromine-methanol } \\
\text { leaching }\end{array}$} \\
\cline { 2 - 5 } & $\mathrm{Ni}$ & $\mathrm{Co}$ & $\mathrm{Ni}$ & $\mathrm{Co}$ \\
\hline 5.3 & 73.20 & 53.92 & $\sim 0$ & $\sim 0$ \\
\hline 10.6 & 82.82 & 58.20 & $\sim 0$ & $\sim 0$ \\
\hline 21.1 & 81.99 & 55.56 & 0.66 & $\sim 0$ \\
\hline 42.2 & 78.84 & 53.90 & 1.99 & 1.20 \\
\hline 84.4 & 70.61 & 41.76 & 6.47 & 12.85 \\
\hline
\end{tabular}

る。また，臭素メタノール法では硫化物態と金属態の両者

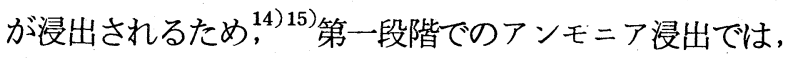
金属態のものがほぼ $100 \%$ 浸出されるように, 多少強夜. $\left(10 \% \mathrm{NH}_{3}, 6 \% \mathrm{SO}_{3}\right)$ で浸出を行なつた。そのため, 表 から明らかなように, アンモニア浸出による $\mathrm{Ni}$, Co の浸 出率は第 8 図のものより多少向上した。残存硫化物の量に 対応すると思われる残渣の臭素メタノール法による $\mathrm{Ni}, \mathrm{Co}$ の浸出率は, ジャロサイト添加量が比較的少ないときはほ とんど0（原子吸光分析の検出限度以下）となり，この範 囲はアンモニア浸出により良好な $\mathrm{Ni}$, Co 浸出率が得られ る範用とほぼ一致している。ジャロサイト添加量が増加す ると,アンモニア浸出残渣を臭素メタノールで浸出したと きの Ni, Coの浸出率が増加し,これは残留硫化物の増加に よるものと推察される。ここで, これらの結果は先の考察 を裏付けるものと思われる。一方, アンモニア浸出および その残渣の臭素メタノール浸出で浸出されなかつた $\mathrm{Ni}$ お よび Coは, 無定形珪酸塩 ${ }^{8)}$ ( (1)式の $\left.\left(\mathrm{Mg}_{1-x} \mathrm{Ni} x\right) \mathrm{Si}_{2} \mathrm{O}_{5}\right)$ や鉄酸化物に，主に酸化物の形で固溶しているものと推定 される。

ウィネ鉱の還元アンモニア浸出において, 焙焼時にジャ ロサイトを比較的少量添加すると $\mathrm{Ni}$ の浸出率が著しく向 上し，これは一時硫化還元反応が起こるためと推定した。 そこで，この反応をより有効にするため，(1)式および(6)式 の分解温度近傍のみを還元焙焼する, いわゆる特定温度領 域昇温同時還元を行なつた。実験はジャロサイト添加量約 $10 \%$ \%のについて行なつた。焙焼は, $823 \mathrm{~K}$ もしくは $873 \mathrm{~K}$ に加熱した炬 (第 2 図) 中に混合試料を入れ，ただ ちに還元を開始し，還元しながら $973 \mathrm{~K}$ まで所定時間かけ て昇温し，焼鉣を取り出した。なお，還元は水素濃度 100 \%に近い強還元性雾囲気で行なつた。焼鉱のアンモニア浸 出条件は以前のもの $\left(6.5 \% \mathrm{NH}_{3}, 3.75 \% \mathrm{SO}_{3}\right)$ と同一で ある。その実駼結果を第 10 図に示した。

実線が $823 \mathrm{~K}$ から $973 \mathrm{~K}$ の範囲を昇温同時還元したもの， 破線が 873 Kから $973 \mathrm{~K}$ 範囲を昇温同時還元したもので ある。なお, 横軸はその温度範囲を昇温するのにかけた時 間, すなわち焙焼時間である。この特定温度領域の昇温同 時還元により $\mathrm{Ni}, \mathrm{Co}$ の浸出率はさらに向上し, $\mathrm{Ni}$ 浸出率

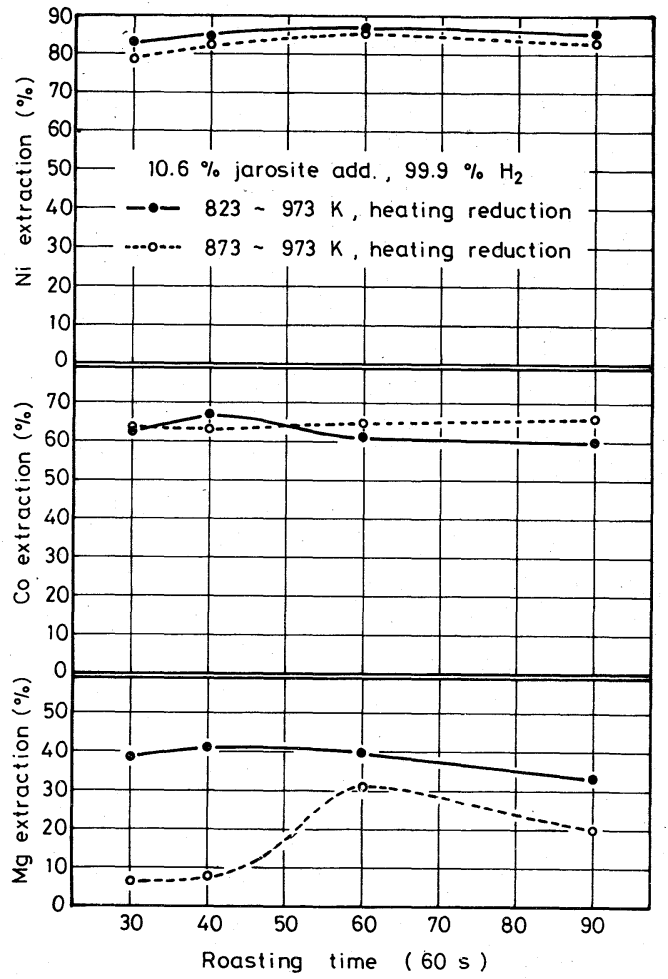

第10図 特定温度領域昇温同時還元における $\mathrm{Ni}, \mathrm{Co}, \mathrm{Mg}$ の浸出率と還元焙焼時間の関係 (ジャロサイト $10.6 \%$ 添加, $\mathrm{H}_{2}$ 濃度 $99.9 \%$ )

は $85 \%$ 以上，Co 浸出率も $65 \%$ 以上という良好な結果が 得られた。これは,この処理により，無定形酸化物に対す るジャロサイトの一時硫化作用がさらに効果的になつたた めと推察される。一方このとき, 理由は不明であるが, $\mathrm{Mg}$ 浸出率も高くなり,これは後の浄液などの点で若干問題 があると思われる。

\section{5. 結言}

高マグネシア酸化ニッケル鉱であるウィネ鉱の還元アン モニア浸出を行ない, ウィネ鉱の被還元性を検討した。ま た, ウィネ鉱に硫酸第 2 鉄もしくはジャロサイトを添加す ることにより，被還元性を向上させることを試みた。その 結果, 以下のことが明らかとなつた。

(1) ウィネ鉱単味の還元アンモニア浸出では, $973 \mathrm{~K}$ 付 近で還元焙焼したとき, $\mathrm{Ni}$, Co の浸出率はともに最高值 を示した。予熱還元と昇温同時還元を比較すると, 昇温同 時還元したときのほうが $\mathrm{Ni}, \mathrm{Co}$ 浸出率は高くなつた。こ れらは, ガーニェライトの脱水反応によつて生成する無定 形酸化物が, フォルステライトに再結晶することなく還元 されやすいためと推察された。

(2) ウィネ鉱に硫酸第 2 鉄やジャロサイトを比較的少量 ( 鉱石に対して $10 \mathrm{wt} \%$ 程度) 添加し, 還元焙焼を行なう と,アンモニア浸出における $\mathrm{Ni}$ 浸出率が著しく向上した。 このとき, 添加したジャロサイトなどは無定形酸化物に対 する一時的な硫化剂として作用し, 被還元性低下の原因で あるフォルステライトへの再結晶を防止し, 被還元性向上 
に役立つたものと推定された。

(3) ガーニエ.ライトの脱水温度とジャロサイトの脱硫温 度の近傍の特定温度領域のみを昇温同時還元すると, Ni 浸 出率は 85 \%以上, Co 浸出率も $65 \%$ 以上となり, 非常に 良好な結果が得られた。ジャロサイトの有効利用という観 点からも，今回の結果は興味あるものと思わ机る。

本研究を行なうに当り, 適切なご助言坴頂いた東京大学 教授 後藤佐吉先生に厚くお礼申し上げる。また, 本研 究費の一部は日本釷業振興会研究助成金によつた。ここに 記して深謝の意を表する。

参考文献

1）白根義則：日本鉱業会誌，81 (1965)，469

2）白根義則：日本鉱業会誌，85 (1969)，1001

3）白根義則：日本鉱業会誌, 89 (1973), 811
4）白根義則：日本鉱業会誌，91（1975)，541

5）沜影和宣・江島辰彦：日本鉱業会誌，94 (1978)，809

6）戸沢一光：東北大学選鉱製鍊研究所巢報，28 (1972)，239

7）伊藤右槄：昭和 52 年度日本鉙業会分科研究会資料 $[G]$ 湿式製鍊, (1977)，G3

8）白根義則・鍬崎尚哉：日本鉱業会誌，96（1980），837

9) M. H. Caron: Trans. Met. Soc. AIME, 230 (1964), 1622

10) J. R. Boldt : The Wining of Nickel, Canada, (1967), 400

11）白根義則·松塚清人：熊本大学工学部研究報告, 9 (1960)，31

12）白根義則・松塚清人：熊本大学工学部研究報告, 10 (1961)，6

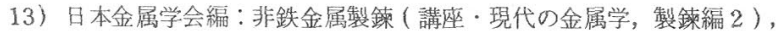
(1980)， 315

14）白根義則：九州鉱山学会誌, 37 (1969), 127

15) P. Urho, P. Veikko, S. Tuomo: Bull. Geol. Soc. Finland, 49 (1977), 79

\title{
Influence of Jarosite on Reduction Roasting for Ammonia Leaching of Nickel Oxide Ore Containing Magnesia at High Amount
}

\author{
by Liangjun YAO $^{1}$, Masayasu KAWAHARA ${ }^{2}$ and Yoshinori SHIRANE ${ }^{3}$
}

In order to investigate the reducibility of Ouinné ore (from New Caledonia) known as nickel oxide ore containing a significant amount of magnesia, reduction roasting and ammonia leaching have been conducted for the ore. Moreover, trials of improving the reducibility have been done by means of adding jarosite to the ore. Sone of results obtained are as follows.

1) Leaching rates of $\mathrm{Ni}$ and $\mathrm{Co}$ in ammonia leaching were improved b heating reduction (simultaneous reduction with heating) as compared with preheat reduction (reduction after preparatory heating). When the ore was roasted by heating reduction in $\mathrm{H}_{2}(50 \%)-\mathrm{H}_{2} \mathrm{O}$ mixed gas atmosphere at $973 \mathrm{~K}$, leaching rates of $\mathrm{Ni}$ and Co were about $65 \%$ and $55 \%$ respectively.

2) When the ore was roasted with a small amount of ferric sulfate or potassium jarosite in the reducing atmosphere, the leaching rate of $\mathrm{Ni}$ improved remarkably in the ammonia leaching. These additives seem to act as sulfidation agent on amorphous oxide temporarily and to prevent crystallization to forsterite of difficult reducibility.

3) When the ore was roasted with about $10 \%$ potassium jarosite in $\mathrm{H}_{2}(99.9 \%)$ atmosphere by heating reduction at temperature between 873 and $973 \mathrm{~K}$ for $40 \sim 50$ minutes, leaching rates of $\mathrm{Ni}$ and Co were $85 \%$ and $65 \%$ or more respectively. These results are also interesting from the point of utilization of jarosite.

1. Research Fellow, Faculty of Engineering, Kumamoto Univ. (at present; Peking Research Institute of Mining and Metallurgy, Peking, China)

3. Prof., Dr., Faculty of Engineering, Kumamoto Unvi,

2. Research Assistant, Dr., Faculty of Engineering, Kumamoto Univ.

\section{第10回ホノルル国際マラソン大会に参加して}

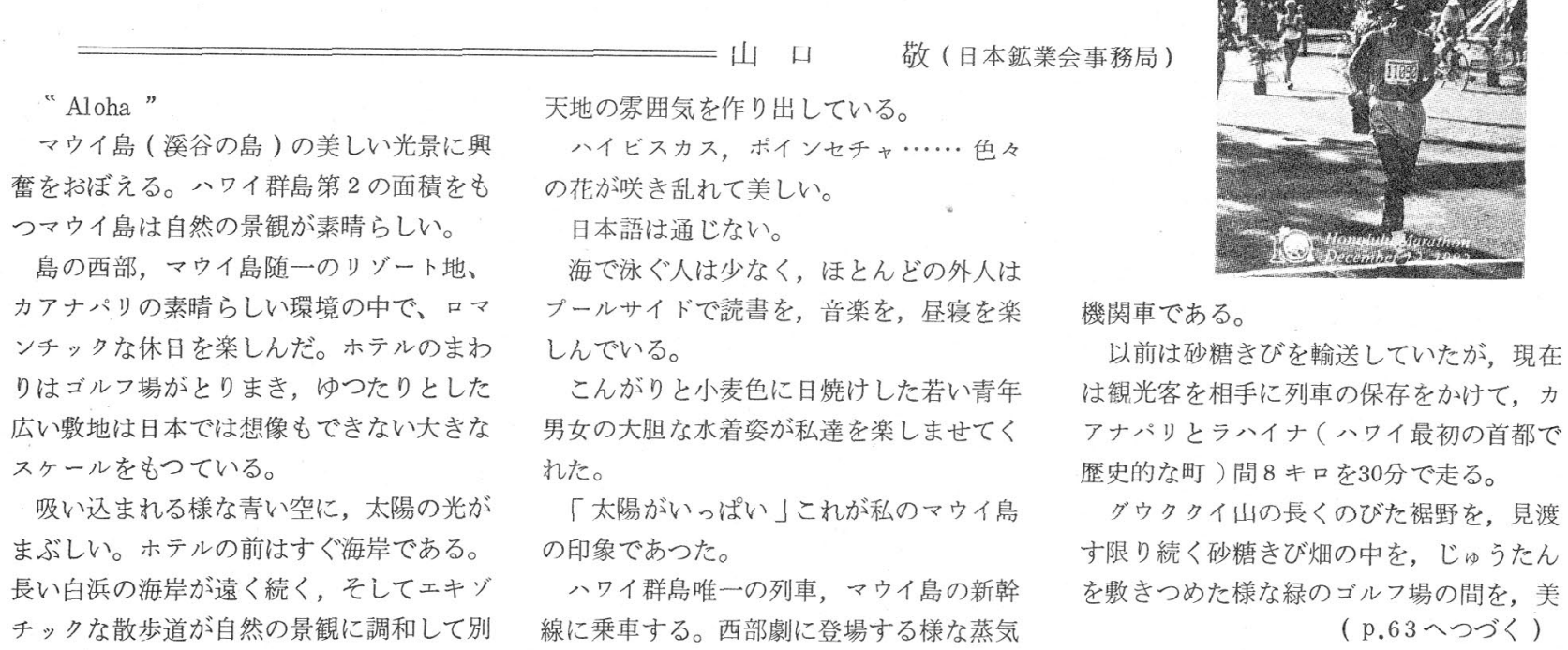

